\title{
On a Matroclinous Plant Appeared from the Crossing, Brassica oleracea L. $\times$ B. pekinensis RUPR.
}

\author{
Hirotoshi Huziwara, Yutaka Mitsushima and Yasuo OMI
}

(Takii Nagaoka Experimental Farm)

Among the interspecific hybrids Brassica olevacea L. var. Yōshinkanran $(n=9) \times$ B. pekinensis Rupr. var. Nozakihakusai $(n=10)$ which embryos were cultured with White's media in spring of 1962, there was a plant which outer characters were very matroclinous but somewhat more rigid and dark-green than her mother plant (Figs. 1, 2, and 3.)
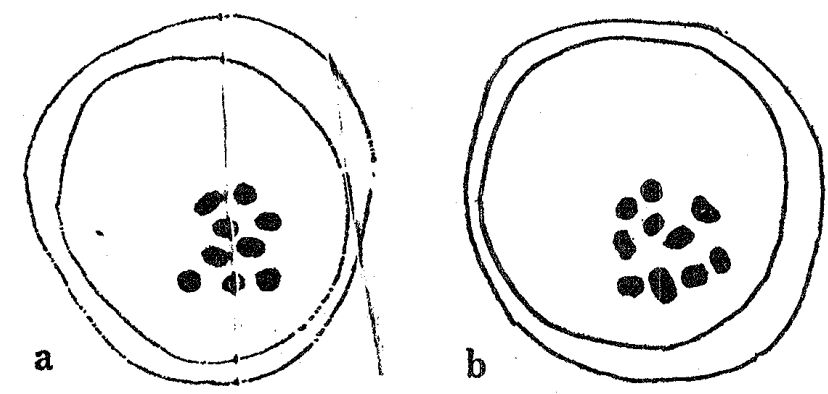

Fig. 1. Gametic chromasomes of parents. $\times$ ca. 2,000

a. B. oleracea $(n=9)$

b. B. pekinensis $(n=10)$

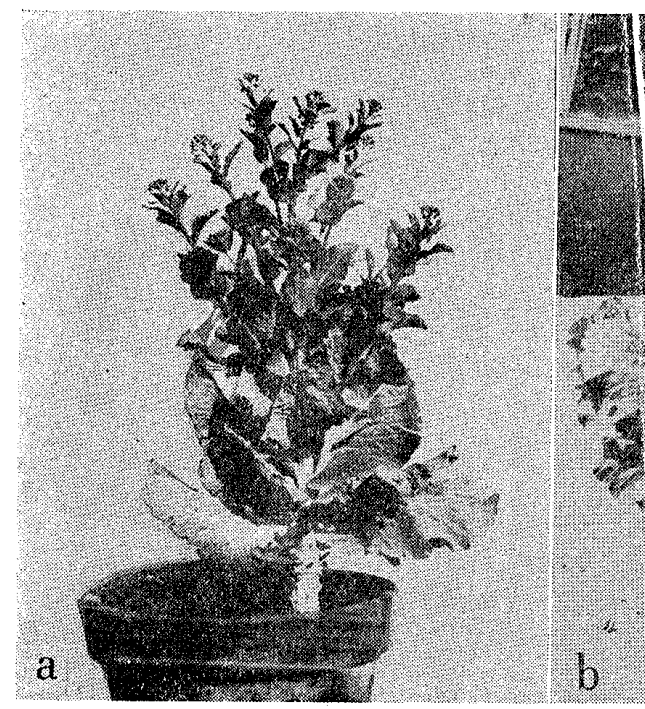

Fig. 2. a. B. oleracea

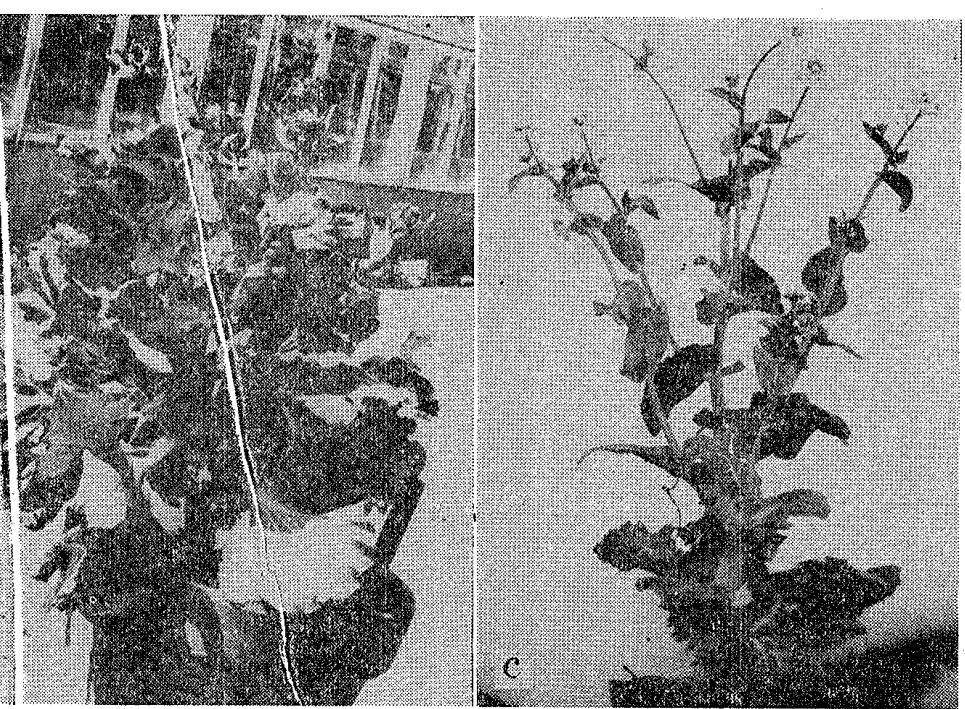

b. Matroclinous hybrid

c. B. pekinensis

After cytological investigations it has been proved that this matroclinous hybrid had 46 somatic chromosomes insteact of expected number 19 (Fig. 4).

Received March 21, 1965 


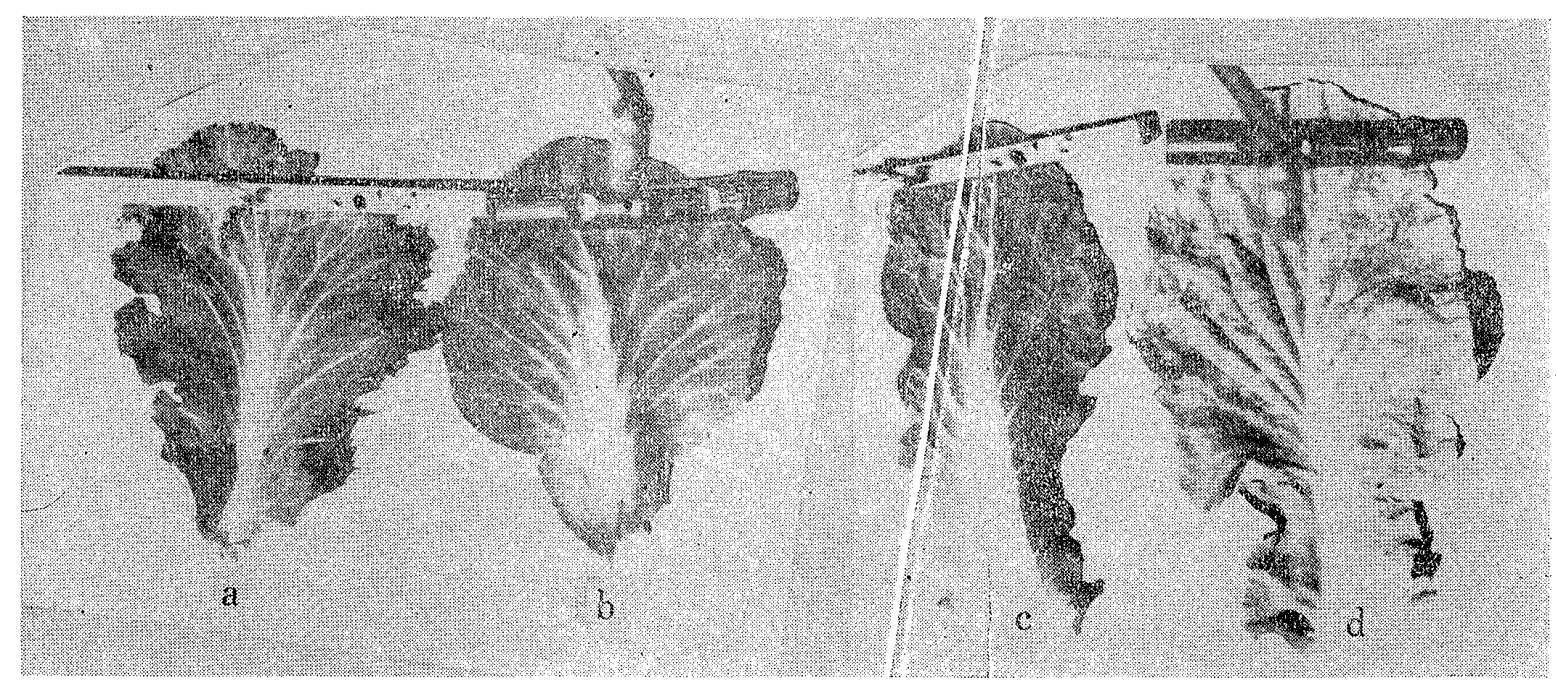

Fig. 3. Shapes of leaves.

a. B. oleracea

b. Matroclinous hybrid

c. Hybrid $(2 n=19)$

d. B. pekinensis
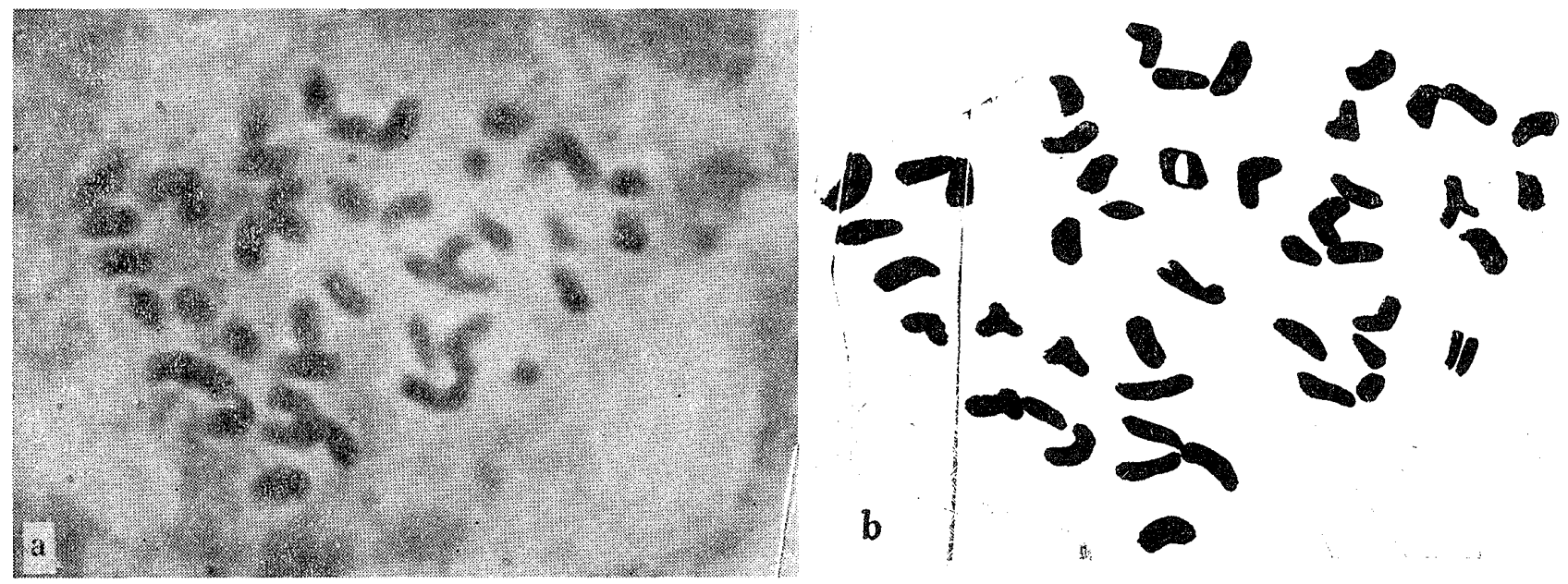

Fig. 4. Somatic chromosomes of matroclinous hybrid. $\times$ ca. 3,000 a, b. in corolla tissue $2 n=46$

Thinking from the matroclinous morphology, it may be assumed that this extra 27 chromosomes are due to quadriplication of maternal set and genomic constitution may be represented as BCCCC (after MorinAGA 1929).

Detailed configurations of chromosome association in MI of this plant could not be examined. So far as observed, a rather few chromosome number in MI was about 17 , and the maximum number of univalent scattered out of equatorial plate was 6 (Fig. 5).

Pollen fertility with aceto-carmine was about 60\% (Fig. 6), but seed fertility was very poor as Table 1 shows.

In Cruciferae, the cases of the duplication of maternal chromosome set by interspecific or intergeneric crossing have been reported at Brassica campestris $\times$ B. oleracea (U 1935), B. oleracea $\times$ Raphanus sativus, $R$. sativus $\times B$. campestris (U, Midusima and SAITo 1937). But the case of quadriplication of maternal set is not yet reported. But 
ShimoтomaI (1933) has reported that each $F_{1}$ plant raised from the crossings, Chrysanthmum Makinoi $(\mathrm{n}=9) \times$ Ch. japonese $(\mathrm{n}=27)$, Ch. Makinoi $(\mathrm{n}=9) \times$ Ch. Decaisneanum $(\mathrm{n}=36)$,
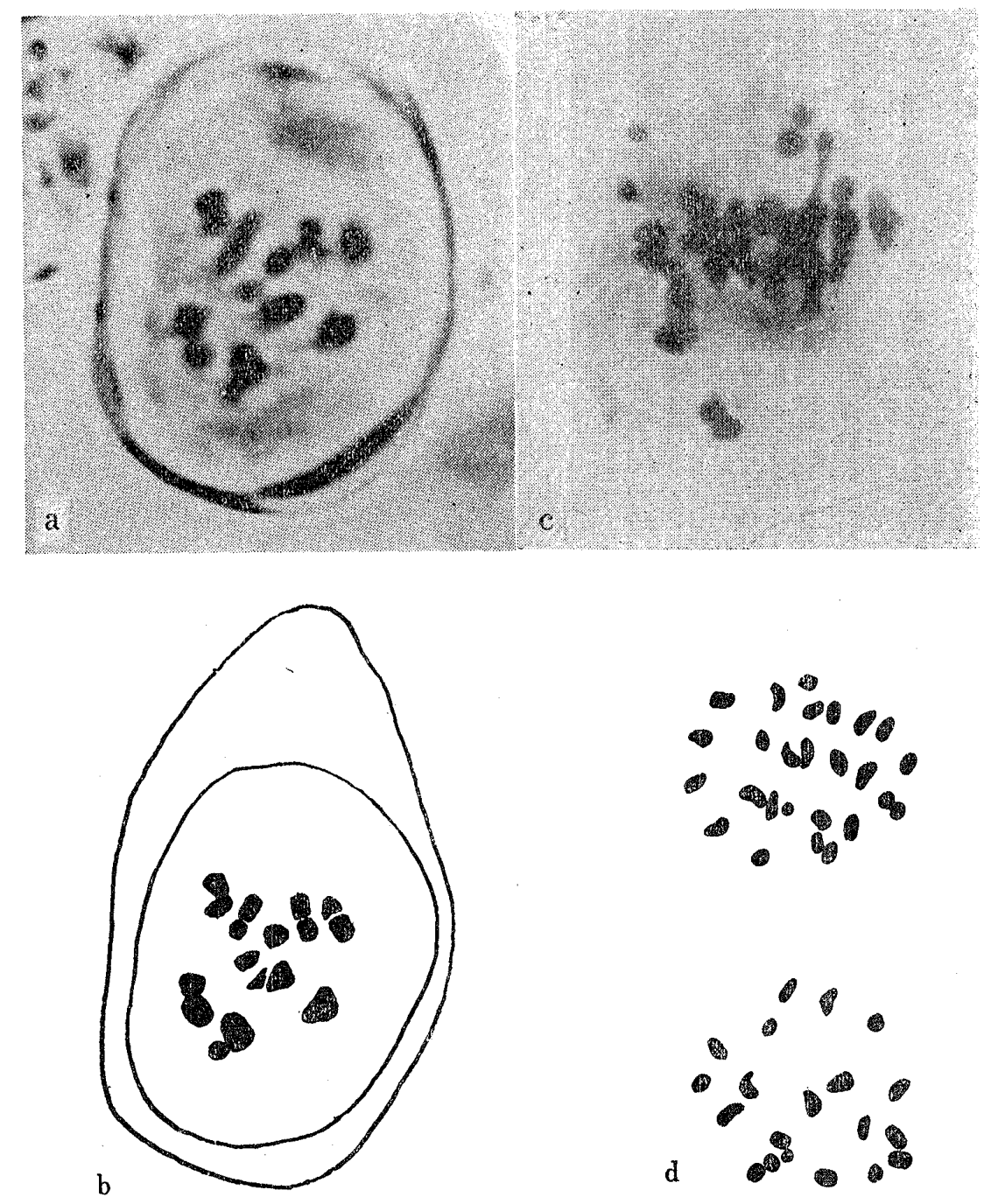

Fig. 5. Chromosomes in meiosis of matroclinous hybrid. $\times$ ca. 2,000

a, b. Polar view in MI (chr. no.= about 17).

c. side view in MI d. 20:26 distribution in TI

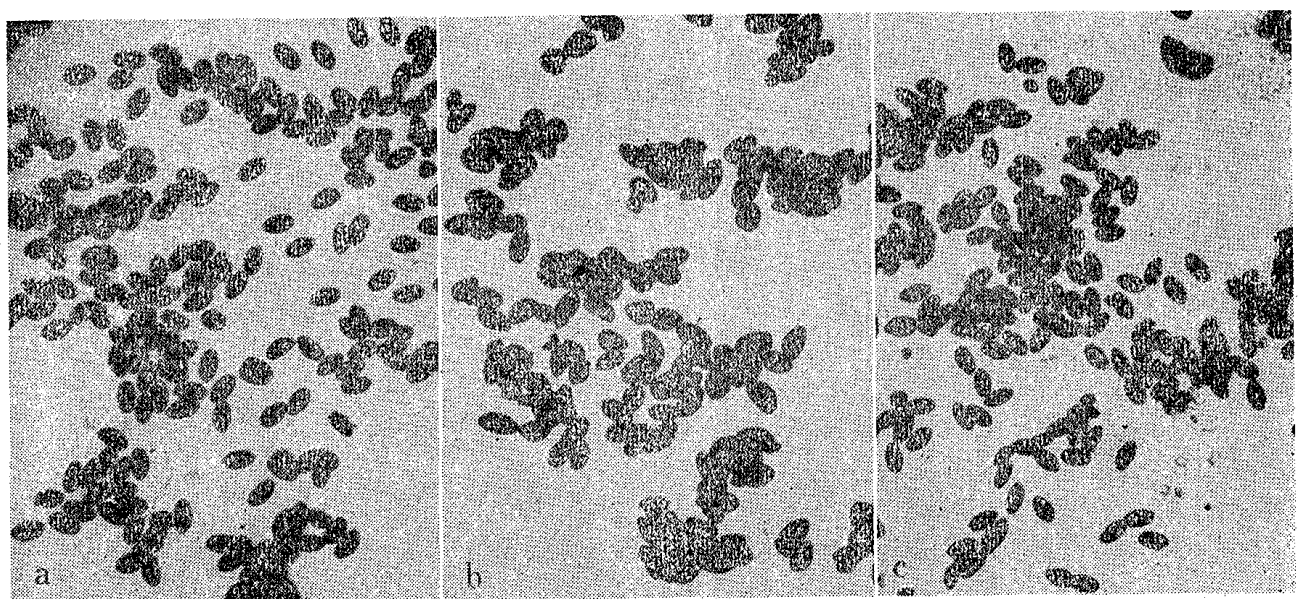

Fig. 6. Pollen. $\times$ ca. 100

a. B. oleracea

b. Matroclinous hybrid

c. B. pekinensis 
Table 1. Results of bud pollination

\begin{tabular}{l|c|c}
\hline Combination of parents & $\begin{array}{l}\text { No. of buds } \\
\text { pollinated }\end{array}$ & $\begin{array}{l}\text { No. of perfect } \\
\text { seeds obtained* }\end{array}$ \\
\hline $\begin{array}{l}\text { Matroclinous plant } \\
\times \\
\text { B. pekinensis }\end{array}$ & 14 & 9 \\
\hline $\begin{array}{l}\text { Matroclinous plant } \\
\times \\
\text { B. oleracea }\end{array}$ & 14 & 0 \\
\hline $\begin{array}{l}\text { Selfing of } \\
\text { matroclinous plant }\end{array}$ & 50 & 21 \\
\hline
\end{tabular}

* An ovary of this matroclinous plant has about 30 ovules.

Ch. Makinoi $(\mathrm{n}=9) \times$ Ch. pacificum $(\mathrm{n}=45)$, had increased chromosome number as many as 27 more than expected numbers. About chromosome increasing mechanism SHIMoTOMAI (1933) described, "Man muss allenfalls annehmen, dass sich hier die Chromosomen aus der mutterlichen Art noch einmal, also in ganzen je zweimal mehr längsweise gespalten hatten.....Es schien mir als ob die obige Annahme tätsachlich zutreffen können." Also with this Brassica matroclinous hybrid, the chromosome increase may be caused by repeated longitudinal splittings of maernal chromosomes in the 1st cleavage of hybrid zygote.

\section{Acknowledgement}

The writers sincerest thanks are due to Dr. T. Morinaga for his kind advices and suggestions.

\section{Literature cited}

Morinaga, T. 1929. The cytology of B. cernua and B. napella. J. Dept. Agr. Kyushu Imp. Univ. 2: 199-206.

SHimotomaI. N. 1933. Zur Karyogenetik der Gattung Chrysanthemum. J. Sci. Hiroshima Univ. Ser. B. Div. 2. 2.

U, N. 1935. Genom-analysis in Brassica with special reference to the experimental formation of $B$. napus and peculiar mode of fertilization. Jap. J. Bot. 7 .

U. N., U. Midushima and K. Saito 1937. On diploid and triploid Brassica-Raphanus hybrid. Cytologia $8: 319-326$.

種間雑種「甘藍 Brassica oleracea L。 $(\mathrm{n}=9)$ 早 $\times$ 白菜 Brassica pekinensis RUPR。 $(n=10)$ 今」にあらわれた傾母個体について 藤原弘俊・光島 豊・臣康 雄 (タキイ長風農場)

胚培養によつて育てた種間雑種「甘藍Brassica oleracea L. $(\mathrm{n}=9)$ 吕 $\times$ 白菜 Brassica pekinensis RUPR. ( $\mathrm{n}=$ 10) §の中に 1 個体甚だ傾母的の外見を旺するるのが女 つた。検鏡の結果この個体は $2 \mathrm{n}=46$ の染色体を有し
「BCCCC」のゲノム構成をもつものと推定された。 授精後第 1 回の細胞分裂の際母方染色体が続いて 2 回 均等分裂を重皇学の結果この㭏な異質 5 倍性傾母個体が できたのではないかと考光ている。 